\title{
The Effect of Welding Residual Stress for Making Artificial Stress Corrosion Crack in the STS 304 Pipe
}

\author{
Jae-Seong Kim, ${ }^{1}$ Bo-Young Lee, ${ }^{2}$ Woong-Gi Hwang, ${ }^{2}$ and Sung-Sik Kang ${ }^{3}$ \\ ${ }^{1}$ Institute for Advanced Engineering, Yongin 449-863, Republic of Korea \\ ${ }^{2}$ School of Aerospace and Mechanical Engineering, Korea Aerospace University, Goyang 412-791, Republic of Korea \\ ${ }^{3}$ Korea Institute of Nuclear Safety, Daejeon 305-338, Republic of Korea \\ Correspondence should be addressed to Sung-Sik Kang; sskang@kins.re.kr
}

Received 5 December 2014; Accepted 3 February 2015

Academic Editor: Tao Zhang

Copyright (C) 2015 Jae-Seong Kim et al. This is an open access article distributed under the Creative Commons Attribution License, which permits unrestricted use, distribution, and reproduction in any medium, provided the original work is properly cited.

\begin{abstract}
The stress corrosion crack is one of the fracture phenomena for the major structure components in nuclear power plant. During the operation of a power plant, stress corrosion cracks are initiated and grown especially in dissimilar weldment of primary loop components. In particular, stress corrosion crack usually occurs when the following three factors exist at the same time: susceptible material, corrosive environment, and tensile stress (residual stress included). Thus, residual stress becomes a critical factor for stress corrosion crack when it is difficult to improve the material corrosivity of the components and their environment under operating conditions. In this study, stress corrosion cracks were artificially produced on STS 304 pipe itself by control of welding residual stress. We used the instrumented indentation technique and 3D FEM analysis (using ANSYS 12) to evaluate the residual stress values in the GTAW area. We used the custom-made device for fabricating the stress corrosion crack in the inner STS 304 pipe wall. As the result of both FEM analysis and experiment, the stress corrosion crack was quickly generated and could be reproduced, and it could be controlled by welding residual stress.
\end{abstract}

\section{Introduction}

Environmentally assisted crack, such as stress corrosion crack (SCC) of the NPP structural materials, has been one of the causes for the shutdown of the power plant resulting in a significant loss, incapacitating the production electric power. The resultant repair and replacement of components in light water reactors (LWR) remains as one of the limiting factors for the safe and economic operation of LWRs, especially in the plant life extension period. Stress corrosion cracking usually occurs when the following three factors exist at the same time: susceptible material, corrosive environment, and tensile stress (including residual stress). Among these factors, the residual stress becomes critical problem for stress corrosion cracking when it is difficult to improve the material corrosivity of the components and their environment under operating conditions $[1,2]$. Generally, the residual stresses are induced by welding process. The welding is mostly used for manufacturing of structure materials such as nuclear power plant and vehicle. Horikawa et al. reported that the crack propagation rate increased at the tungsten inert gas- (TIG-) welded joint. Tani et al. reported that chloride induced SCC of the austenitic stainless steel occurred independently of the tensile residual stress value. They have performed the SCC test on the austenitic SS using loading device and showed that the specimen of type 304L SS was fractured even when the applied stress was below $200 \mathrm{MPa}$ which was less than $0.2 \%$ proof stress of type 304L SS [3]. Most of the studies have used the slow-strain-rate test (SSRT), which is not useful for studying the effect of stress level [4]. Since the research of Mazille and Rothea, $[5,6]$ it is well known that Ni-based alloy and stainless steel are susceptible to stress corrosion cracking (SCC) in deaerated pure water at high temperature, but the test was performed in autoclave which is possible to contain a specimen. The conventional method of manufacturing artificial stress corrosion cracks is difficult to imitate environmental conditions of the NPP because the resulting cracks are not obtained by using a pipe actually used for equipment of nuclear power plants but by using a simulation specimen. 




FIGURE 1: The stress corrosion crack forming equipment.

In this study, the stress corrosion crack was artificially produced on the materials of the nuclear power plant by using the custom-made device. The device provided real environment of nuclear power plant and the semiautomatic GTAW process was used for giving the residual stress in the inner of the pipe. The fracture time, which is defined by pressure drop in a SCC test, of the STS 304 pipe was used to confirm the residual stress effect by welding heat input. Also, 3D FEM (Finite Element Method) analysis model is designed about STS 304 pipe and performed heat transfer analysis and residual stress analysis.

\section{Experimental Methods}

2.1. Forming the Stress Corrosion Crack. The test material was austenitic STS 304, which is used as pipelines in the Reactor Coolant System of nuclear power plants (O.D. = $89 \mathrm{~mm}, t=7.7 \mathrm{~mm}$ ). The stress corrosion crack forming equipment is shown in Figure 1. The equipment for forming stress corrosion cracks consisted of heater, pressure sensor, AE (acoustic emission) sensor, load cell, and DAQ (data acquisition) system, and so forth. Generally, an autoclave was used to make an environment condition of high pressure and high temperature for making a SCC. But, in this study, the autoclave was not used. The heating coils were directly imposed on the surface of pipe to generate high steam pressure and temperature of inner pipe, and the inside of pipe specimen was filled with corrosive solutions. The test was performed using the stainless steel 304 pipe in $2 \mathrm{M} \mathrm{Na}_{2} \mathrm{SO}_{4}$ and $1 \mathrm{M} \mathrm{NaOH}$ solutions. The length of specimen is $150 \mathrm{~mm}$. Table 1 shows mechanical properties of the STS 304. The yield stress of the STS 304 material is $139 \mathrm{MPa}$ and vapor pressure of the specimen according to ideal gas equation is 165 bar at $350^{\circ} \mathrm{C}$. In this case, hoop stress was $124 \mathrm{MPa}$ caused by vapor pressure.

The GTAW process was used for the combined action of the chemical environment and the residual stresses in the custom-made system. Figure 2 shows the semiautomatic GTA welding system for giving the residual stress. And Table 2 is the welding conditions for GTAW.

2.2. For Inducing Residual Stress Inner Pipe. Table 3 shows experimental conditions for welding. We welded an inner pipe using the same condition on the same line. Figure 3

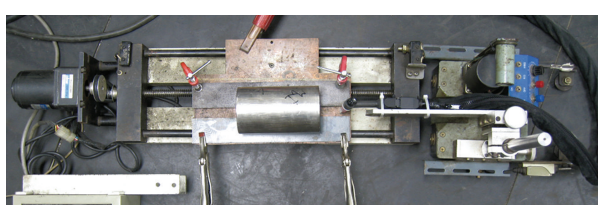

FIGURE 2: The semiautomatic GTA welding system for giving the residual stress.



FIGURE 3: BOP bead inner STS 304 pipe.

shows BOP (Bead on Plate) bead inner of the pipe using the GTAW process.

2.3. 3-D FEM Analysis. For the heat transfer analysis, we had divided a step of heating and cooling analysis for each pass by using the thermal physical properties of STS 304 according to temperature and typically melting point of steel. Table 4 shows thermal physical properties of STS 304 according to temperature. For the FEM stress analysis, we predicted a variation of the welding residual stress using the thermal physical properties and boundary conditions, which is a temperature variation by heat transfer analysis [7]. The commercial code ANSYS 12 was used for the nonlinear heat transfer analysis and stress analysis. Figure 4 shows 3D FEM meshed model of piping. Element type was selected for 70, 3D thermal solid model and 45, 3D structural solid model. The number of node was 14904, and the number of elements was 12558.

2.4. For Evaluating Residual Stress Test. We used the instrumented indentation technique to evaluate the residual stress values in the GTAW area (see Figure 5). The measuring positions of residual stress, as seen in Figure 5, are 5, 10, and $30 \mathrm{~mm}$ spot from the welding center line.

\section{Results and Discussion}

3.1. Fabrication of the SCC. The stress corrosion crack was fabricated using the custom-made manufacturing system. Figure 6 shows the temperature and pressure variation during the test. The maximum temperature and pressure, which were measured at $358^{\circ} \mathrm{C}$ and 157 bar by thermocouple and pressure sensor, were similar environmental condition in the nuclear power plant. It was confirmed that the new forming equipment for artificial stress corrosion cracks could be simulated by the environmental conditions in the NPP. The vapor pressure was decreased after about 5 hours.

It was confirmed that the pipe was fractured by stress corrosion crack. This means that the crack was already initiated before leaking. The vapor pressure induced hoop stress in the pipe. Circumferential stress in a cylindrical shaped part as a result of internal or external pressure is 
TABLE 1: Mechanical properties of STS 304.

\begin{tabular}{lccccc}
\hline Properties & Modulus of elasticity & Yield strength & Tensile strength & Elongation & Hardness (Hv 1) \\
\hline STS304 & $193 \mathrm{GPa}$ & $410 \mathrm{MPa}$ & $669 \mathrm{MPa}$ & $66.5 \%$ & 200 \\
\hline
\end{tabular}

TABLE 2: Welding conditions of GTAW.

\begin{tabular}{lc}
\hline Welding current $(\mathrm{A})$ & 90 \\
Welding voltage $(\mathrm{V})$ & 21 \\
Welding speed $(\mathrm{cm} / \mathrm{min})$ & 30 \\
Shielding gas & Ar $100 \%$ \\
\hline
\end{tabular}

TABLE 3: Experimental conditions for giving residual stress.

\begin{tabular}{lc}
\hline Specimen number & $\begin{array}{c}\text { Welding pass } \\
\text { (on the same } \\
\text { line) }\end{array}$ \\
\hline W1 & 1 \\
W2 & 5 \\
W3 & 10 \\
W4 & 13 \\
W5 & 15 \\
\hline
\end{tabular}

TABLE 4: Physical properties of the STS 304 according to temperature.

\begin{tabular}{|c|c|c|c|}
\hline Temperature & 30 & 200 & 400 \\
\hline $\begin{array}{l}\text { Specific heat } \\
\text { (cal/g-k) }\end{array}$ & 0.114 & 0.119 & 0.123 \\
\hline Poisson's ratio & 0.290 & 0.304 & 0.321 \\
\hline $\begin{array}{l}\text { Young's modulus } \\
\text { (MPa) }\end{array}$ & 197227.1 & 182054.5 & 164204.461 \\
\hline $\begin{array}{l}\text { Thermal expansion } \\
(1 / c)\end{array}$ & $1.63 E-05$ & $1.63 E-05$ & $1.6282 E-05$ \\
\hline $\begin{array}{l}\text { Thermal conductivity } \\
(\mathrm{cal} / \mathrm{s}-\mathrm{cm} \mathrm{k})\end{array}$ & 0.037 & 0.049 & 0.062 \\
\hline Yield strength (MPa) & 258.608 & 169.209 & 125.321 \\
\hline Temperature & 600 & 800 & 1000 \\
\hline Specific heat (cal/g-k) & 0.131 & 0.143 & 0.150 \\
\hline Poisson's ratio & 0.337 & 0.354 & 0.362 \\
\hline $\begin{array}{l}\text { Young's modulus } \\
(\mathrm{MPa})\end{array}$ & 146354.401 & 128504.3 & 119592.7 \\
\hline $\begin{array}{l}\text { Thermal expansion } \\
(1 / c)\end{array}$ & $1.6282 E-05$ & $1.63 E-05$ & $1.63 E-05$ \\
\hline $\begin{array}{l}\text { Thermal conductivity } \\
\text { (cal/s-cm k) }\end{array}$ & 0.076 & 0.089 & 0.098 \\
\hline Yield strength (MPa) & 113.0189 & 91.448 & 88.350 \\
\hline
\end{tabular}

called hoop stress. In a closed pipe such as our specimen, force applied to the cylindrical pipe wall by a rising inner pressure will ultimately induce hoop stress. During the test, maximum vapor pressure was 157 bar; that is, hoop stress of the inner surface was more than $87 \%$ of yield stress. It is estimated that stress corrosion crack was accelerated by additional hoop stress as well as susceptible material, corrosive environment, and including residual stress. Many

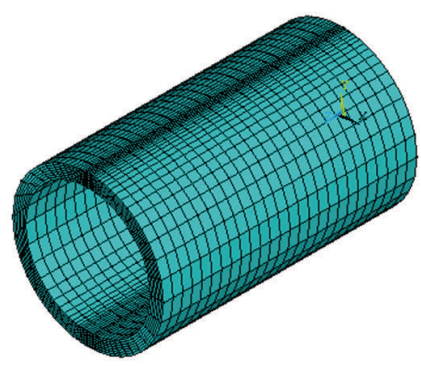

FIgURE 4: Meshed model of piping.

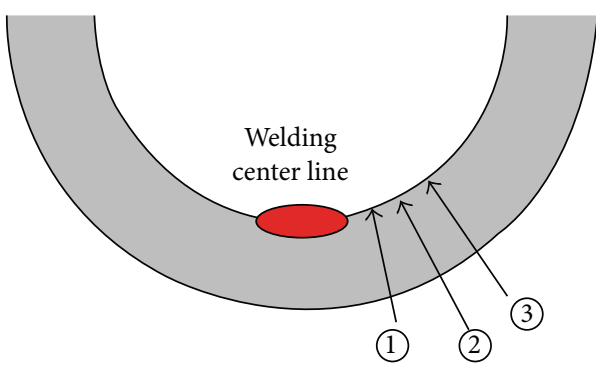

(1) $5 \mathrm{~mm}$

(2) $10 \mathrm{~mm}$

(3) $30 \mathrm{~mm}$

from welding center line

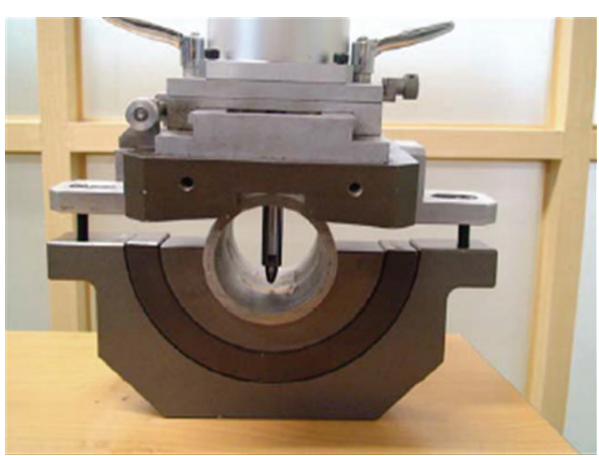

FIGURE 5: Evaluation of residual stress using the instrumented indentation technique.

cracks in the inner surface (a top and bottom view) of the pipe were observed by the visual test. Figure 7 shows the outer shape of the specimen and cross section $(\times 12.5)$ of the inner surface pipe at the cutting 1 . Figure 8 is the optical microscope fractography of points (a), (b), (c), and (d) at cutting 1. It is confirmed that the cracks were propagated along the grain boundary. The intergranular stress corrosion cracks were clearly revealed, which was a typical character for primary water stress corrosion crack in major pipes of pressurized water reactor. 




FIGURE 6: Temperature and pressure in STS 304 pipe.

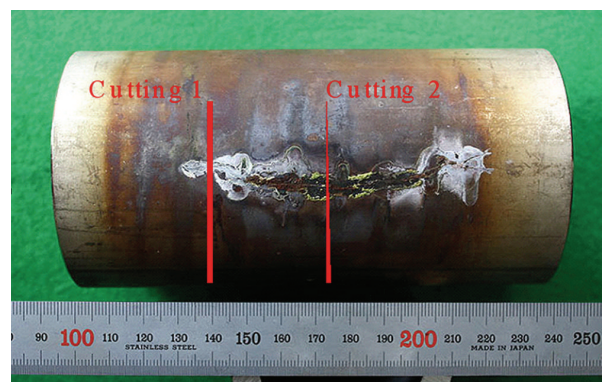

(A)

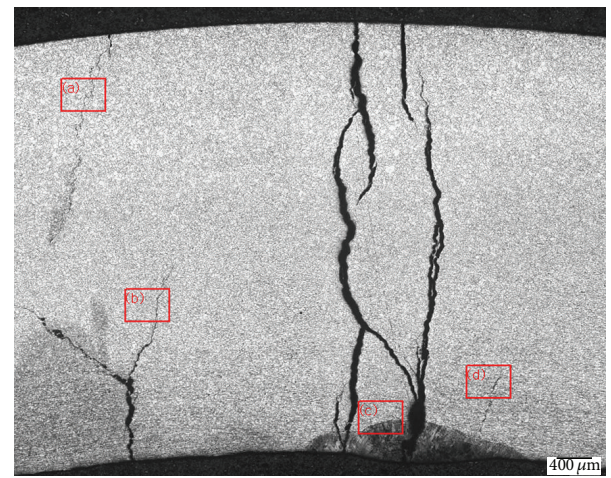

(B)

FIgURE 7: Outer shape of the specimen and cross section.

3.2. The Results of FEM Analysis. Because the melting point of STS 304 was about $1400^{\circ} \mathrm{C}$, the bead temperature of the first welding pass was decided as $1400^{\circ} \mathrm{C}$ and it was assumed that the temperature would be increased by additional welding pass. The heating time was the same as welding time. The cooling time was decided as $10 \mathrm{~min}$ in the FEM analysis, because the experimental cooling time was $10 \mathrm{~min}$. The heat input of the pipe (volume energy per hour) was modified by a temperature of the HAZ (Heat Affected Zone). The temperature variation calculated by thermal transfer analysis was used as boundary condition for analysis of the residual stress in the pipe. Figure 9 shows a temperature gradient of the specimen after first welding pass.

Analysis was bilinear kinematic hardening method using Von Mises or hill plasticity. Figure 10 shows thermal properties of bilinear kinematic hardening for STS 304.

Figure 11 shows the results of circumferential (hoop) maximum tensile residual stress in the inner surface of the pipe. The residual stress is the highest at 90 100 degree position which was well corresponded to position of crack appearance. The tensile residual stress of the FEM analysis confirmed that the number W1 specimen is the lowest, and 

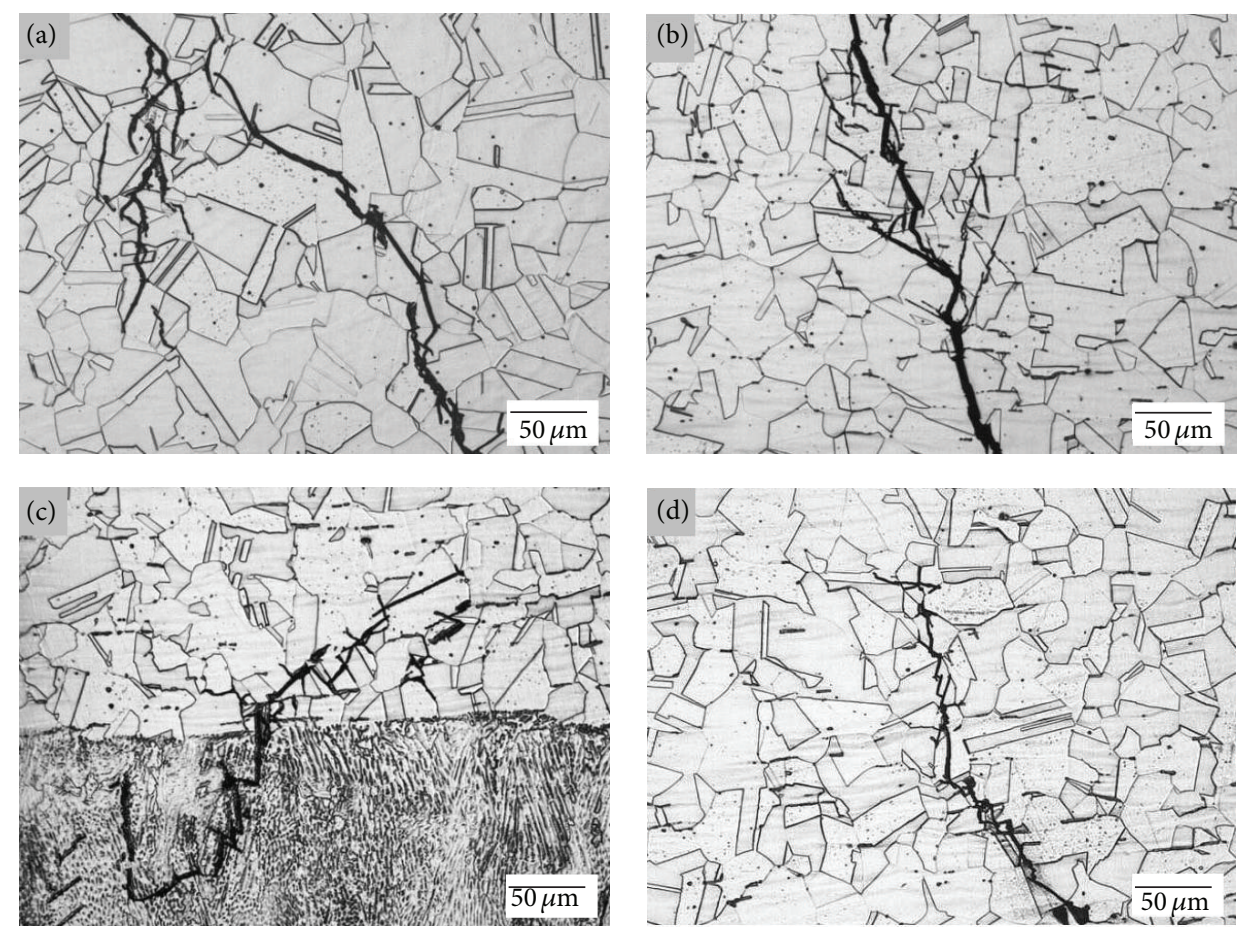

FIgURE 8: Fractography of points (a), (b), (c), and (d) at cutting 1.

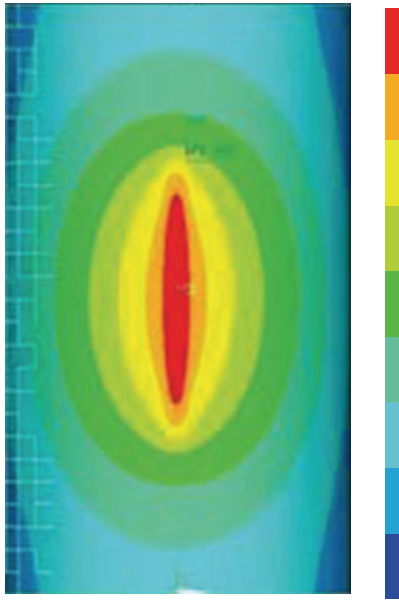

685.330

625.967

566.604

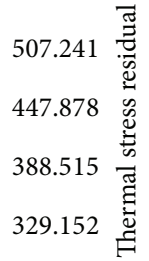

269.789

210.426

151.063

FIGURE 9: Temperature gradient of specimen after first welding pass.

the others are of similar level. So, we selected and evaluated an instrumented indentation test for the specimens of number W1 and number W3.

3.3. The Effect of the Residual Stress. Figure 12 shows the result of residual stress for $\mathrm{W} 1$ and $\mathrm{W} 3$. The maximum position of the residual stress is about $15 \mathrm{~mm}$ from welding center line. The residual stress value of W3 was about $20 \mathrm{MPa}$ higher than that of W1. This means that increasing of welding pass has made a residual stress higher than the first welding pass. Table 5 shows relationship between number of welding pass and the fracture time of pipe. All the experimental conditions



FIGURE 10: Bilinear kinematic hardening table for STS 304.

such as corrosion environment, heating temperature, and welding condition are the same. So it can be considered that difference of through-wall fracture time is effects of residual stress. The fracture time of the specimen W5 that was welded by 15 pass was relatively shorter than other conditions. And it is well corresponded to the highest tensile residual stress at the 90 100 degree position in Figure 11.

Figure 13 shows a shape and position of artificial stress corrosion crack using the SCC forming device. Even though 


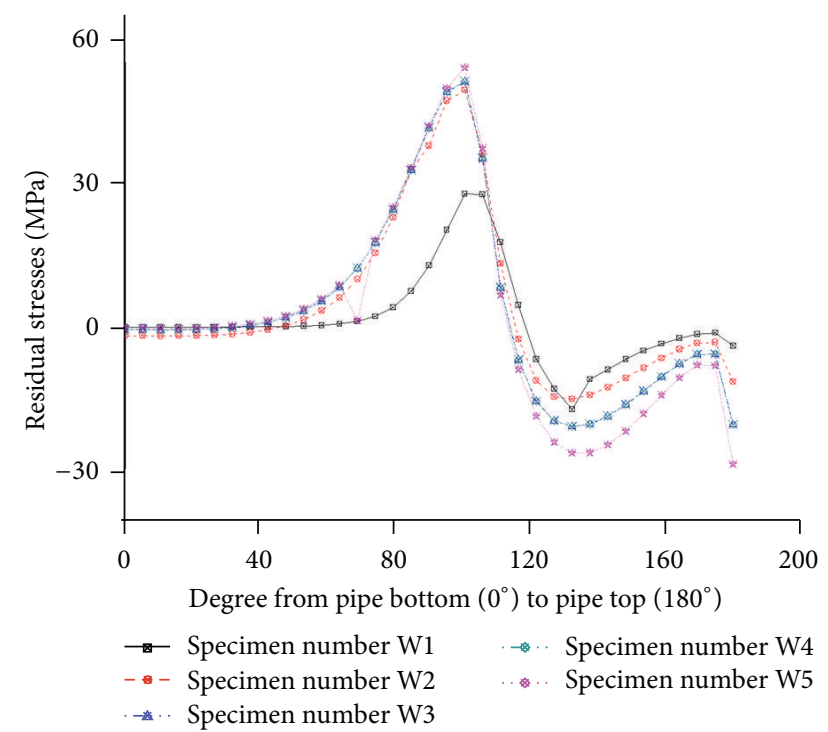

FIgURE 11: Hoop residual stress distribution.

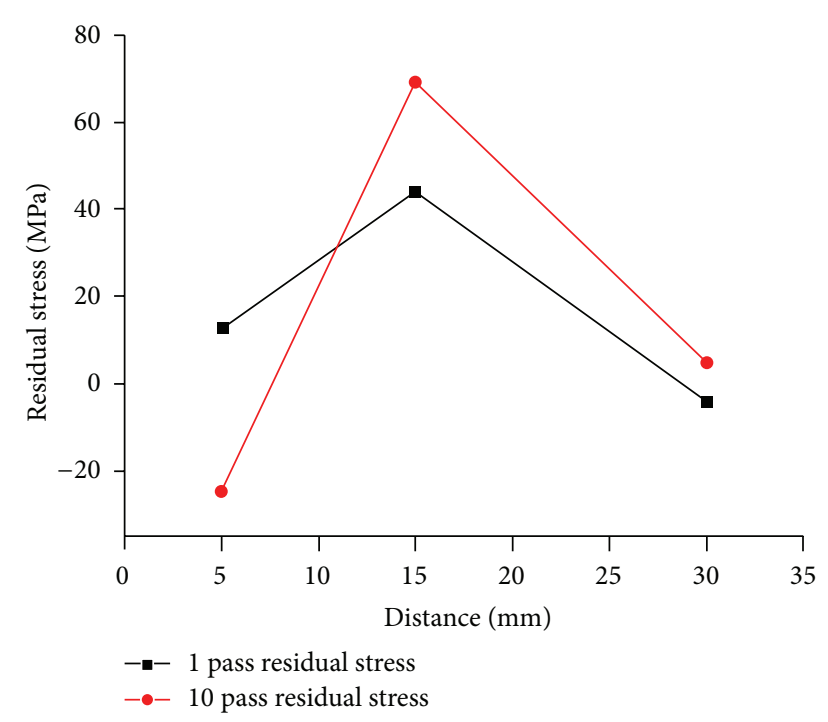

FIGURE 12: Residual stress graph on inner surface of STS304 pipe.

TABLE 5: The fracture time of STS 304 pipe.

\begin{tabular}{lccc}
\hline Specimen number & Pass number & $\begin{array}{c}\text { The fracture } \\
\text { time (min) }\end{array}$ & Inner pressure \\
\hline W1 & 1 & 787 & 192 \\
W2 & 5 & 646 & 120 \\
W3 & 10 & 132 & 127 \\
W4 & 12 & 323 & 144 \\
W5 & 15 & 294 & 157 \\
\hline
\end{tabular}

the SCC was initiated at a random position, it was confirmed that SCC was affected by a residual stress in the same environment.

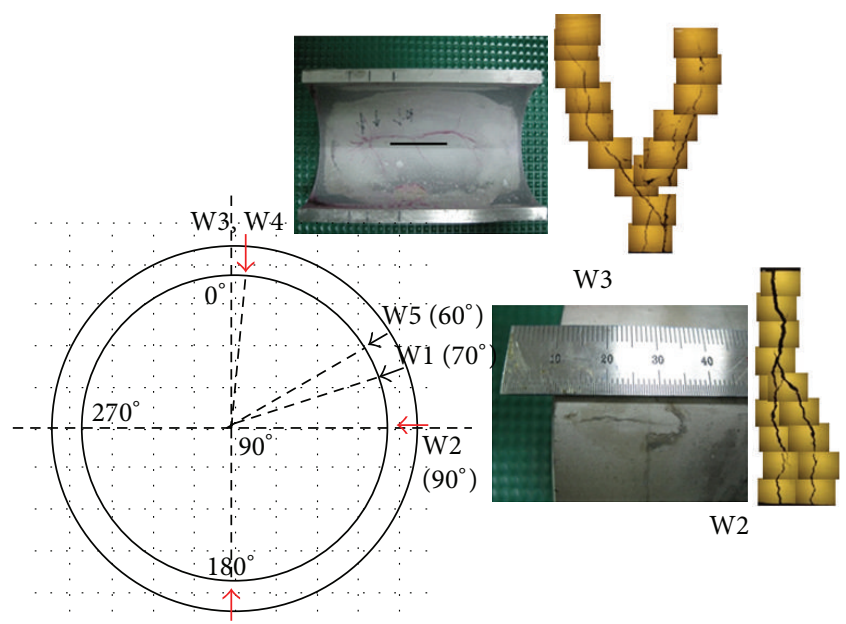

FIGURE 13: Artificial SCC shape and position according to experimental conditions.

\section{Conclusions}

(1) The custom-made device was used, which simulated an environment condition of NPP (nuclear power plant), for fabricating the stress corrosion crack in the inner pipe wall. And stress corrosion crack was artificially produced on STS 304 pipe by a welding residual stress.

(2) The residual stress was increased by increasing welding pass. The fracture time of the pipe by stress corrosion cracking was decreased by increasing residual stress according to welding heat input. Even though the SCC was initiated at a random position, it was confirmed that SCC was affected by a residual stress under the same environment.

(3) The new system was developed for manufacturing stress corrosion crack in the inner surface of the pipe specimen. And it is possible to manufacture mass SCC production of real size pipes in our system.

\section{Conflict of Interests}

The authors declare that there is no conflict of interests regarding the publication of this paper.

\section{Acknowledgments}

This work was supported by the Korea Radiation Safety Foundation (KORSAFE) funded by National Safety and Security Commission (NSSC). Test equipment was supported by the National Research Foundation (NRF).

\section{References}

[1] M. Mochizuki, "Control of welding residual stress for ensuring integrity against fatigue and stress-corrosion cracking," Nuclear Engineering and Design, vol. 237, no. 2, pp. 107-123, 2007. 
[2] H. S. Yu, H. D. Jeong, D. Y. Lyu, and S. H. Chung, "A study on the stress corrosion cracking evaluation for weld joint of TMCP steel by SP-SSRT method," Journal of KWS, vol. 15, no. 2, p. 1, 1997.

[3] S. Eto, Y. Miura, J. Tani, and T. Fujii, "Effect of residual stress induced by pulsed-laser irradiation on initiation of chloride stress corrosion cracking in stainless steel," Materials Science and Engineering A, vol. 590, pp. 433-439, 2014.

[4] H. Coriou, L. Grall, M. Pelras, and S. Vettier, Third Metallurgy Conf. on Corrosion, Saclay, North Holland, Amsterdam, The Netherlands, 1959.

[5] H. Mazille and R. Rothea, "The use of acoustic emission for the study and monitoring of localized corrosion phenomena," in Modelling Aqueous Corrosion, vol. 266 of NATO ASI Series: Series E Applied Sciences, pp. 103-127, Springer, Dordrecht, The Netherlands, 1994.

[6] A. C. E. Sinclair, D. C. Connors, and C. L. Formby, "Acoustic emission analysis during fatigue crack growth in steel," Materials Science and Engineering, vol. 28, no. 2, pp. 263-273, 1977.

[7] J.-Y. Nam, D.-H. Seo, S.-Y. Lee, W.-K. Hwang, and B.-Y. Lee, "The effect of residual stress on the SCC using ANSYS," Procedia Engineering, vol. 10, pp. 2609-2614, 2011. 

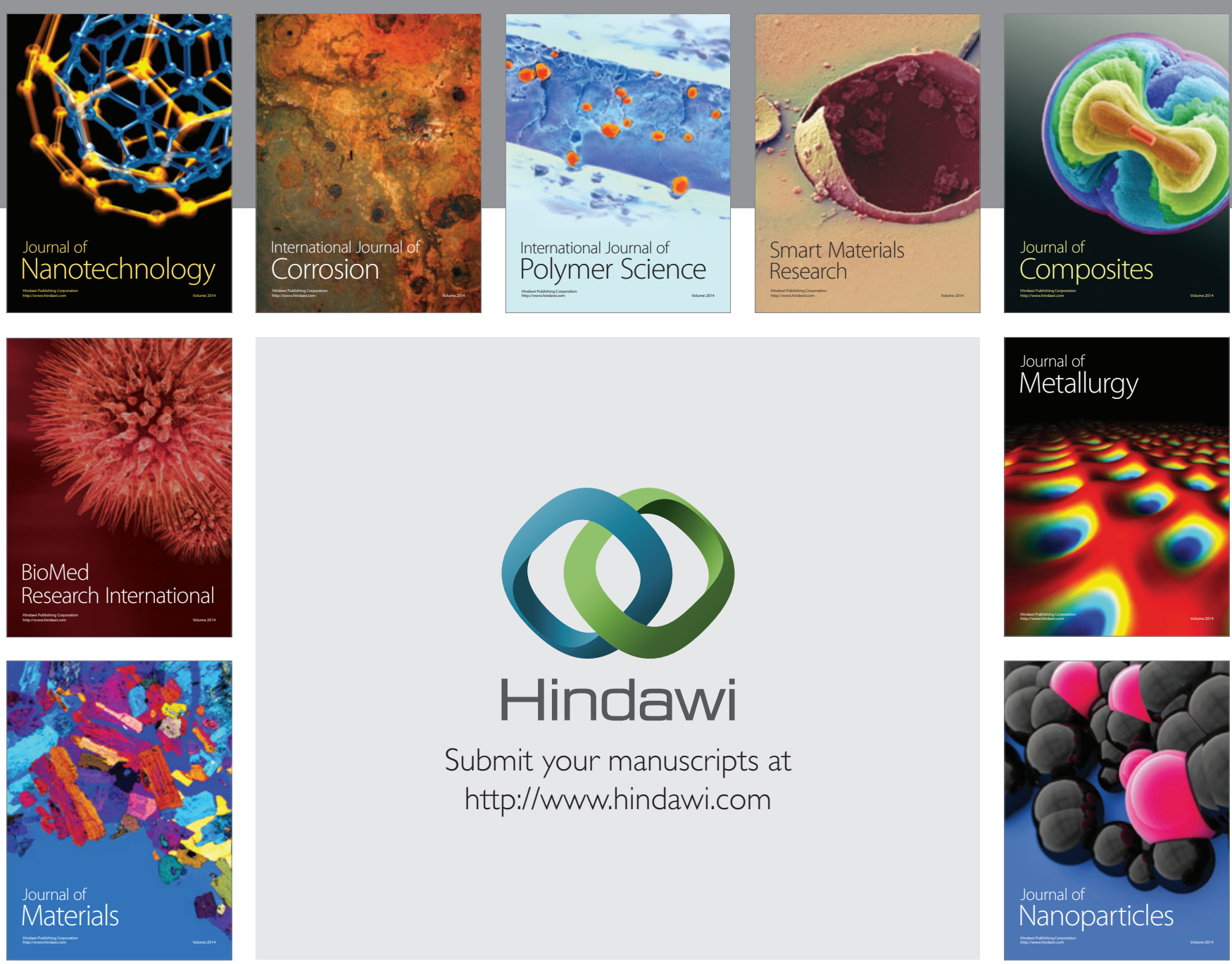

Submit your manuscripts at http://www.hindawi.com
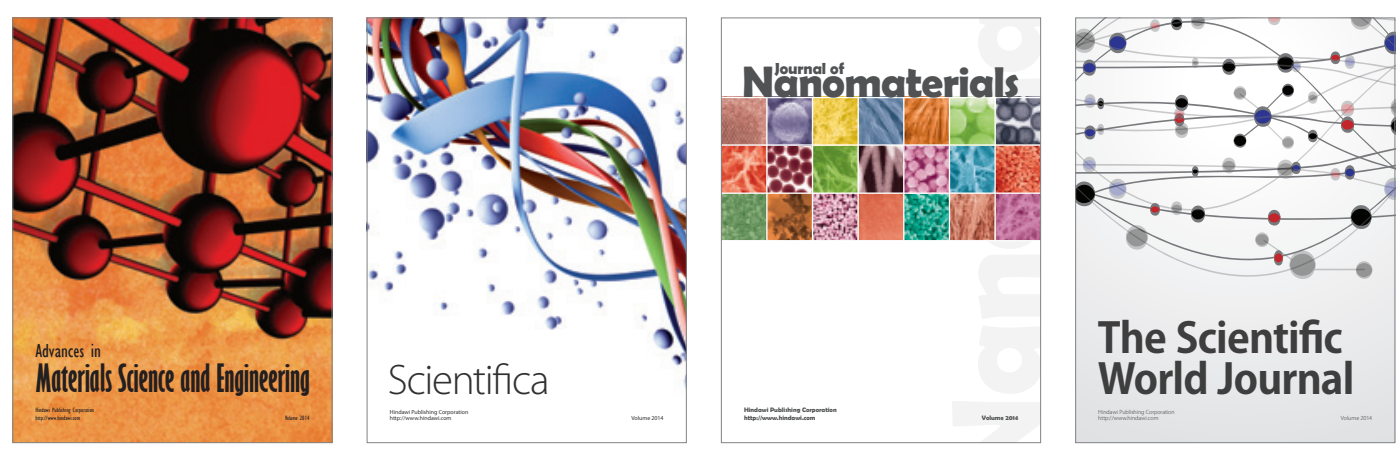

\section{The Scientific World Journal}
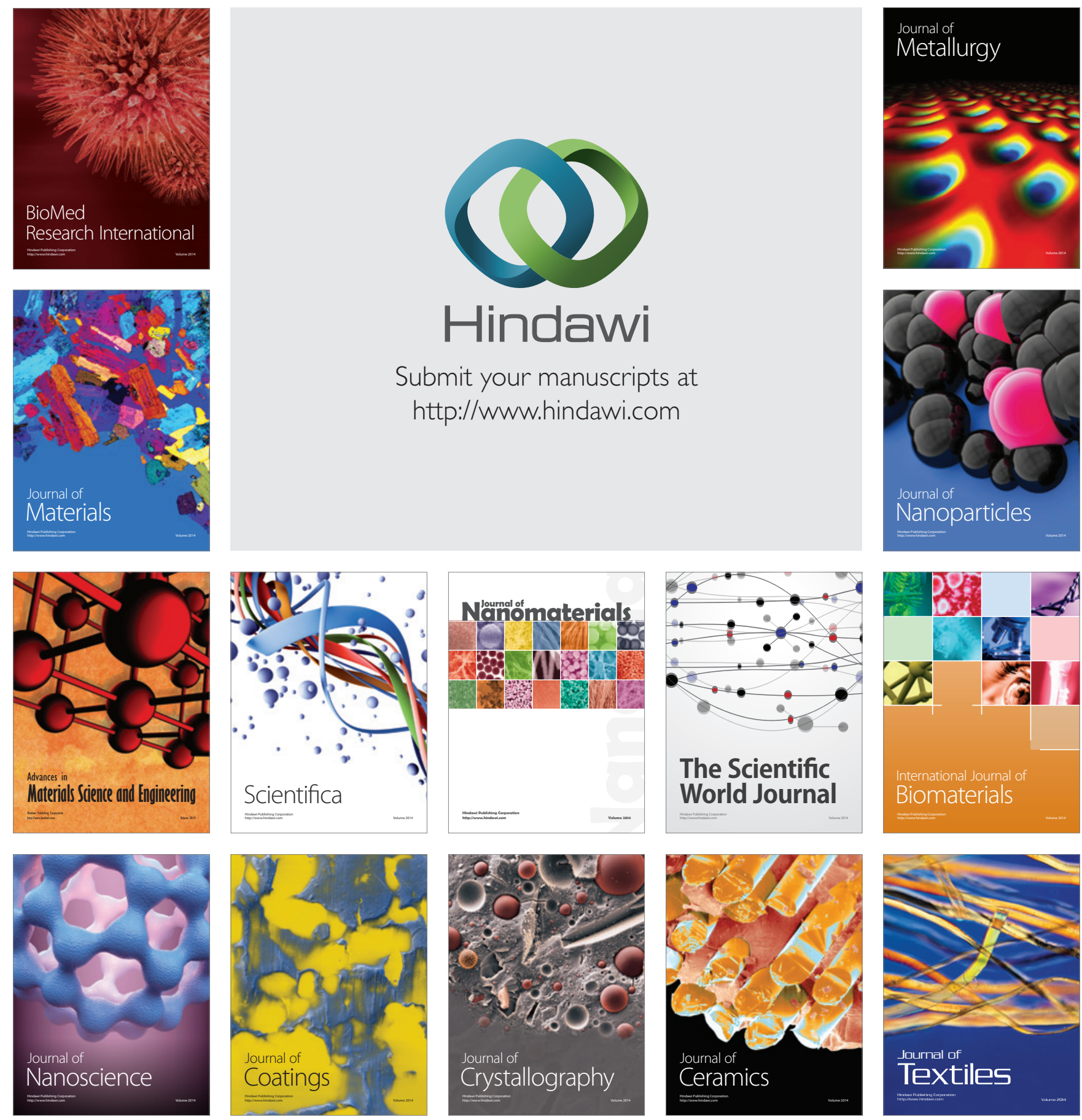